\title{
PHYTOGEOGRAPHICAL IMPORTANCE OF THE MOUNTAINS ALONG THE DANUBE MOUNTAIN GAP VALLEY AND SURROUNDING AREA
}

\author{
Erika SCHNEIDER-BINDER *
}

* KIT - University of Land Baden-Württemberg and National Research Centre of the Helmholtz Society, Institute for Geography and Geo-ecology, Department WWF-Institute for floodplains ecology, Josefstrasse 1, Rastatt, Germany, D-76437, erika.schb@t-online.de

DOI: 10.1515/trser-2015-0030

KEYWORDS: thermophilous and xero-thermophilous species, Mediterranean, Sub-Mediterranean and Balcanic floristic elements.

\begin{abstract}
The Danube mountain gap valley between Romania and Serbia is known for its high biodiversity, represented by many xero-thermophilous species, phytocoenoses and habitats of Southern origin. The occurrence of these species and phytocoenoses is strongly related to the geographical position on the continent, with related climate conditions and the geomorphological structure. The different phyto-geographical regionalisation highlights the uniqueness of the area, being the meeting point of species with their Northern, Southern, Western or Eastern limit in the Danube Gorge break. Here are presented the identifying species of characteristic phytocoenoses, threatened species and typical habitats with relevance for the European Natura 2000 network.
\end{abstract}

REZUMAT: Importanţa fitogeografică a Clisurii Dunării şi a zonelor adiacente.

Clisura Dunării situată între România şi Serbia este cunoscută pentru excepţionala sa biodiversitate, care este reprezentată prin numeroase specii, fitocenoze şi habitate xerotermofile de origine sudică. Prezenţa acestor specii şi fitocenoze este strâns legată de poziţia geografică pe continent, condiţiile climatice şi structura geomorfologică. Diferitele regionalizări fitogeografice scot în evidenţă particularitatea acestei zone, aceasta fiind punctul de întâlnire al speciilor care ating limita nordică, sudică, vestică sau estică în jurul clisurii. Sunt prezentate speciile edificatoare ale fitocenozelor caracteristice din zonă, speciile cu statut de periclitate şi habitate cu relevanţă pentru reţeaua Europeană Natura 2000.

ZUSAMMENFASSUNG: Die pflanzengeographische Bedeutung des Durchbruchtals der Donau und angrenzender Gebiete.

Das zwischen Rumänien und Serbien liegende Durchbruchtal der Donau ist bekannt für seine außergewöhnliche Biodiversität, die sich durch viele xero-thermophile Arten, Phytozönosen und Habitate submediterraner Herkunft auszeichnet. Das Vorkommen dieser Arten und Pflanzengesellschaften ist eng gebunden an die geographische Lage auf dem Kontinent, die Klimabedingungen sowie die geomorphologische Struktur. Die unterschiedlichen pflanzengeographischen Gliederungen heben die Besonderheiten des Gebietes hervor, die den Treffpunkt vieler Arten darstellt, deren nördliche, südliche, westliche oder östliche Verbreitungsgrenze im Gebiet des Donaudurchbruchs liegt. Vorgestellt werden die Bestand bildenden Arten der charakteristischen Pflanzengesellschaften, Arten mit ihren Gefährdungskategorien sowie die für das Natura 2000 Netzwerk relevanten Habitattypen. 


\section{INTRODUCTION}

The mountains along the Danube mountain gap valley, also known as the Danube Gorge break valley of the South-Western Carpathians between Serbia and Romania are famous for their outstanding biodiversity. In comparison with other parts of the Carpathians this is the most thermophilous corner, sheltering many xerophilous and thermophilous species of Mediterranean, Sub-Mediterranean, Illyric, Balcanic, Pontic-Mediterranean and Pontic-Balcanic affinity. The occurrence of these species is related to the geographical position on the continent of the "Clisura" Gorge system, with related climate conditions, combined with other determining factors - especially the geomorphological structure related to a diverse mosaic of geological substrate, with limestone, serpentine, crystalline schist and other rocks (Mutihac, 1972; Posea, 2002; Săndulescu et al., 1978).

This geology creates specific site conditions that contribute to the large variety of macro- and microhabitats in the region of the Danube Gorge. Related to the geomorphological structure and substrate that produces varied soil conditions, the inclination of the slopes and the effects of insolation contribute as well to the large variety of site conditions reflected in the occurrence of various macro- and microhabitats, biocoenoses, communities and species.

The uniqueness of the area reflects influences of the Sub-Mediterranean climate, leading to many varied considerations regarding the classification and integration of the area in a system of bio- respectively zoo- and phytogeographical or floristic-geo-botanical regions (Borza, 1931a, b; Ciocârlan, 2009; Borza and Boşcaiu, 1965; Călinescu, 1969; Horvat et al., 1974; Popova-Cucu, 1978).

According to Borza (Borza and Boșcaiu, 1965) in the geobotanical-floristic regionalization of Romania, the South-Western part of the Carpathian Mountains in the Banat area is included within the group of Southern Carpathian crystalline mountains (Carpaţii Meridionali cristalin - in Romanian), as a unit of the Banat Mountains (Oraviţa Mountains) including also the Semenic Mountains. The calcareous mountains along the Danube cross valley, the so called "Clisura" are not included here. The above-mentioned mountains are characterized by a thermophilous vegetation cover of Mediterranean, Illyrian and Balcanic-Asiatic species. Besides the beech forests characterised by European beech (Fagus sylvatica), at the montane level one can also mention Oriental beech (Fagus orientalis) and Taurian beech (F. taurica), Turkish hazel (Corylus colurna) and Athamantha hungarica, a species of Apiaceae, as characteristic elements. In this category too are included as well the mountains on the left side of the Cerna River.

The lower calcareous mountains in the immediate vicinity of the Danube break gorge are included, according to Borza (Borza and Boșcaiu, 1965) in the Daco-Illyrian Province characterized by oak forests dominated by Turkey oak (Quercus cerris), with Hungarian oak (Quercus frainetto), Downy oak (Quercus pubescens) and Silver lime (Tilia tomentosa). This province presents a belt-like zone of variable size in the Western foothill area of the country, running along the Danube cross valley. It includes also the middle and lower part of the Cerna Valley and the hilly area along the southern foot of the Southern Carpathians and a part of the Danube Plain as far as the arc of the Carpathians and Southern Moldova (Meusel and Niedermaier, 1985). The vegetation of this area is - as these authors conclude - of Illyrian origin, and extends westwards to the foot of the Alps and as well to the South and East as far as Anatolia. This province is almost congruent with the 
geomorphological subunits of the area. On the southern border of the Southern Carpathians it corresponds to the Getic Plateau and the Carpathian Mountains (Carpaţii de curbură). The Getic subunit of Oltenia of the Daco-Illyrian Province ("Circumscripţia getică a Olteniei") includes forests of Quercus frainetto, Fraxinus ornus, Carpinus orientalis, Danaa cornubiensis (Physospermum cornubiense (L.) DC.), Helleborus odorus, Smyrnium perfoliatum, Physocaulis nodosus, Cynosurus echinatus and many Southern clover (Trifolium) species. On the rocky slopes occurs the endemic Black pine of Banat, Pinus nigra ssp. banatica. At Vârciorova Dianthus pinifolius, Prangos carinata and other Mediterranean species can be found.

The Banat subunit of the Daco-Illyrian province extends between the Danube River, Semenic Mountains and Poiana Ruscă and is characterized by thermophilous species such as Trifolium subterraneum, Tamus communis, Acanthus longifolius, Fagus orientalis, Symphytum ottomanum, Asperula taurina, Ruscus aculeatus, Ruscus hypoglossum, Saponaria glutinosa, Cerastium banaticum, Seseli gracile, Seseli rigidum and Athamantha hungarica. To the above-mentioned species should be added Spurge laurel (Daphne laureola), previously mentioned from the area (Roman, 1972a; Sârbu et al., 2013) and found during our field activities in tributary valleys of the Danube: Mraconia, Ponicova, Valea Rea, and Sirinia.

The Poiana Ruscă Mountains, which make the connection between the Banat Mountains and the Western Mountains (Munţii Apuseni) North of the Mureş River with Biharia, display strong South-Western influences in the flora without being characterized by endemic and relict species. But they shelter some xerothermic species such as Wild lilac (Syringa vulgaris), Wild vine (Vitis sylvestris), Smoke bush (Cotinus coggygria), Oriental hornbeam (Carpinus orientalis) and other xero-thermophilous and thermophilous species which are characteristic for these mountains (Borza and Boşcaiu, 1965). These species have a larger distribution in the Southern Banat, the mountains along the Danube cross valley and in the Cerna and Mehedinţi Mountains as well (Meusel and Niedermaier, 1985). At the same time they are also characteristic for the mountains on the right side of the Danube cross valley of Serbia, the Miroc and Liskovac Mountains (Niculae, 2014; Horvat et al., 1974).

According to Popova-Cucu (1978) the Poiana Ruscă and the entire Banat Mountains with the mountains along the Danube cross valley are included in the Dacian Province (Banat-Getic Sub-Province) of the Macaronesian-Mediterranean Region (SubMediterranean Sub-Region), a categorisation which underlines the sub-Mediterranean character of the area of the Clisura. According to the phytogeographical regionalisation of Romania by Ciocârlan (2009) the Danube Gorge is part of the District of Banat and Poiana Ruscă Mountains in the frame of the Carpathian Province. The bio-geographical classification of Călinescu (1969) presents the area of Clisura and the Banat Mountains inclusive of the lower part of the Cerna Valley mountains as a part of the Moesian Province, but the Cerna middle and upper part as part of the Dacic province.

These differing opinions concerning the phytogeographical zonation, but at the same time other converging opinions, are understandable in such an area situated on a crossing point of Central - South-West European, Daco-Illyrian and Moesian influences. Confirming Borza and Boşcaiu (1965), the limit between the Daco-Illyrian province and the Central-European-Eastern Carpathians Province is unclear, present as gradual transitions, with interlocking of the distribution area of plants, phytocoenoses and habitats, depending on relief, slope angle and aspect. 
Frequently the Danube mountain crossing and the Cerna Valley are considered as separate units due to their special and high biodiversity. The occurrence of many Southern Mediterranean, Illyric and Balcanic species that reach the limits of their distribution in the area along the "Clisura" or in the mountains of Southern Banat has long attracted scientists.

Studying the different vegetation maps including the Danube Gorge break area, they represent clearly the characteristics of a transition zone from Central to Southern i.e. SouthEastern Europe and the interlocking and overlapping of different phyto-coenological units. On the map of the natural vegetation of Danubian countries (Niklfeld, 1973), the Danube Gorge break is represented as a belt with woods identified by Oriental hornbeam (Carpinus orientalis) and Downy oak (Quercus pubescens), a smaller area with Quercus frainetto, Quercus cerris forests and Balcanic submontane Sessile oak and Sessile oak-Quercus cerris forests, partly with hornbeam. Central and South European montane beech forests identified by Fagus sylatica are represented as well on the surrounding hills and valleys (Figs. 1 and 2).

On the vegetation map of Romania for the Clisura area are represented as characteristic vegetation units the Quercion petraeae, Quercion frainetto and Carpinion alliances, phytocoenological units of Fagus sylvatica var. moesica and secondary grasslands of Danthonio-Chrysopogonetum. In the neighbouring Nera Valley area occur also forests identified by Quercus petraea, with Fraxinus ornus and Carpinus orientalis of the association Orno-Quercetum praemoesicum (Doniţă and Roman, 1976). The detailed maps of the Danube Gorge break vegetation on the stretch between Tri-Kule and Ieşelniţa (Resmeriţă et al., 1972), as well between Orşova and Drobeta-Turnu Severin (Roman, 1972b) present the characteristic phytocoenological units for the area, with between them many associations of sub-Mediterranean and Mediterranean character.

According to the biogeographical regions (Doniţă et al., 2005) the Danube Gorge break is included in the continental region. But this classification is too general to allow a detailed view for the Danube Gorge break area, as all details of Mediterranean, subMedietarranean and Balcanic influences become lost.

The objective here is to analyse and to emphasise the characteristics of the Danube Gorge break area from the phytogeographical point of view with its characteristic species, with those reaching their limit of distribution in the Danube Gorge break area and its surroundings and also the species identifying characteristic plant communities and habitats.

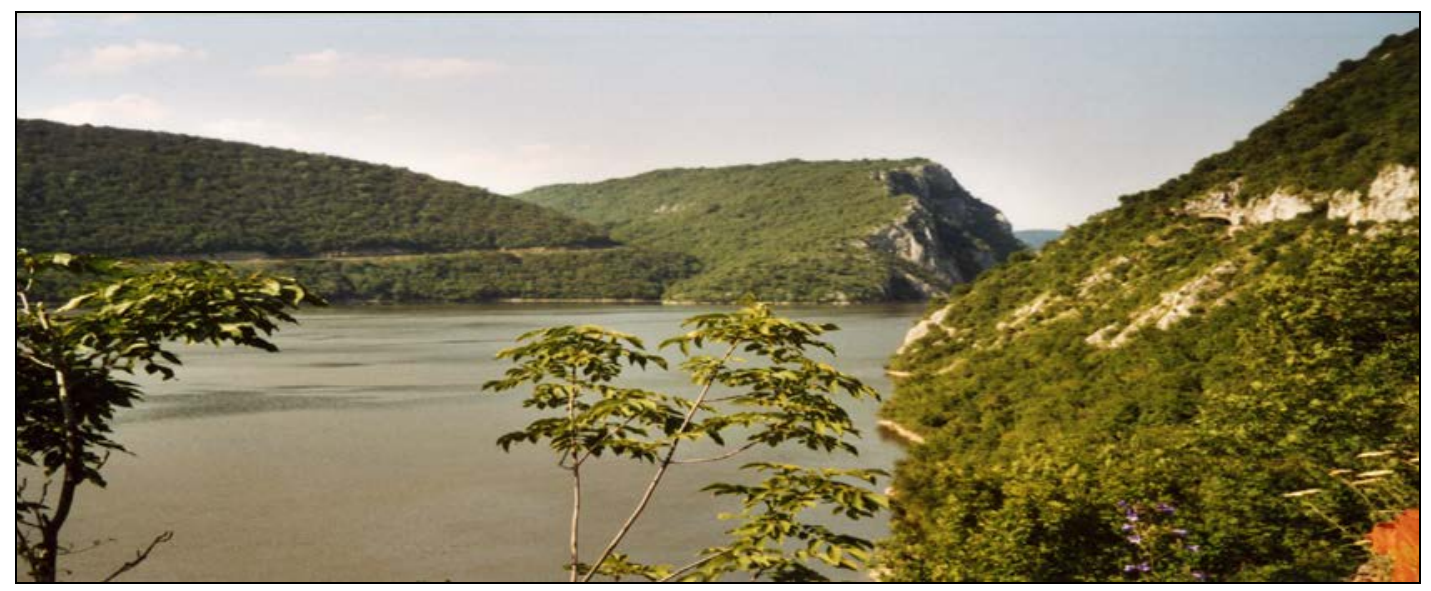

Figure 1: The Danube Gorge break valley. View from the Serbian side. 


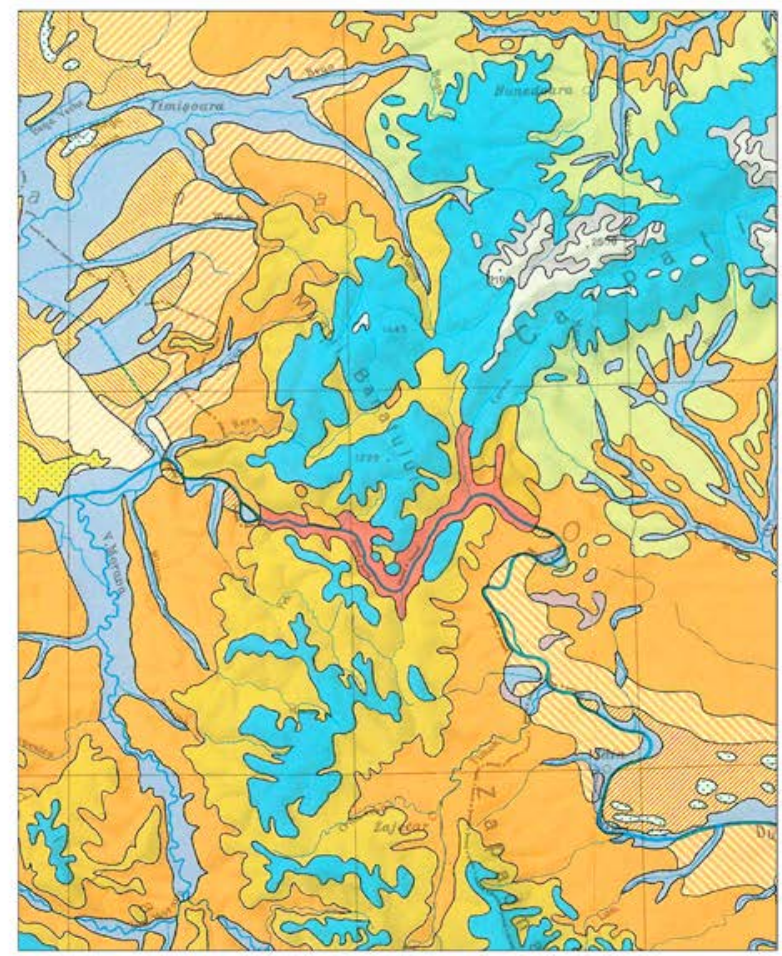

Carpinus orientalis - Quercus pubescens woods of coastal regions; on mountain slopes

Quercus frainetto - Qu. cerris-forests typical formation

Balkanic submontane Sessile Oak (and Sessile Oak-Quercus cerris) forests

Oak-hornbeam forests of Central European hill and mountain regions, mostly with participation of Quercus petraea

Central and South European montane beech forests, mixed forests of beech with Abies alba and Picea abies

Picea abies and P. abies-Abies alba forests of Central European to inner Balkanic mountain ranges

Subalpine scrubs of Pinus mugo and of Alnus viridis; dwarf shrub heaths of Dwarf Juniper and Ericaceae; alpine grassland

Submediterranean-influenced forest-steppes on loess with Quercus pubescens, Qu. cerris, Qu. petraea, Qu. robur

Submediterranean-influenced forest-steppes on loess, with Quercus pedunculiaflora, Qu. frainetto

Pannonian forest-steppes on sandy soils, mostly with Quercus robur

Loess steppes of the Pannonian plain, scattered with oak woods and scrubs

Sand and loess steppes along the lower Danube, scattered with oak woods and scrubs

Thracian forest-steppe region; partly with oak woods and scrubs

Riparian forests: oak-elm, poplar and willow forests

Flat bogs and alder swamp forests

Vegetation complexes of brackish swamps, salt meadows, communities of halophilious succulents, and Artemisia-Festuca pseudovina steppes

Figure 2: Natural vegetation of the Danube Gorge break and surrounding area (Natural vegetation by Niklfeld 1973 map 171 detail in the "Atlas of the Danubian countries"). 


\section{MATERIAL AND METHODS}

To highlight the particularities of the Danube Gorge break valley, a list of characteristic species for the various habitats has been compiled, based on the author's earlier and recent research $(2014,2015)$. Attention was given on the one hand to thermophilous and xero-thermophilous species of Daco-balcanic, sub-Mediterranean and Mediterranean distribution area identifying characteristic phytocoenoses in the Clisura and surrounding area, and on the other hand to rare species which have their distribution limits in the "Clisura Dunării" or neighbouring area (Dihoru and Negrean, 2009). For these species Red List categories (IUCN criteria) are given according to the Red Book of vascular plants of Romania (Dihoru and Negrean, 2009): EX (extinct), CR (critically endangered), EN (endangered), VU (vulnerable), LR (low risk), and DD (data deficient). The other species were grouped according to their geographical distribution and analysed in the context of biogeographical zoning of the area in relation to their phyto-coenological affiliation, being characteristic for certain associations occurring in the study area. Species nomenclature follows Ciocârlan (2009), Dihoru and Negrean (2009) and Sârbu et al. (2013).

The different associations were analysed and discussed using comparative data from the surrounding area and adjacent biogeographical zones. To exemplify the Mediterranean character of some phytocoenoses of the Danube Gorge break, an analysis of phytogeographical elements was realised using published data (Boşcaiu et al., 1971), and unpublished data of the author for two associations Echinopo banatici-Quercetum pubescentis Boşcaiu 1971 and Syringo-Carpinetum orientalis Jakucs 1959.

The associations mentioned and inventoried from the area were included in the habitat types according to the Interpretation Manual of the European Union habitats (EUR 28, 2013).

\section{RESULTS AND DISCUSSION}

Analysing the characteristic elements of the flora of the Danube cross valley it becomes clear that the uniqueness is achieved by the presence of a great number of subMediterranean and Mediterranean, Pontic-Mediterranean and Balcanic xero- to xeromesophilous and thermophilous- to meso-thermophilous species. Some are identifying species for the characteristic phytocoenoses of the area and distinct elements in the natural landscape of the Danube cross valley.

In addition to the identifying species of characteristic phytocoenoses, have to be mentioned also species, which occurs frequently in many phytocoenoses, being differential for vegetation units of the Danube mountain gap valley. This fact is clearly visible if we compare them with phytocoenoses of other phytogeographical regions in the CarpathianDanubian region. All together they are noted below grouped into categories of floristic elements according to their distribution area.

\section{Woody species}

Mediterranean flora elements: Celtis australis L.;

Sub-Mediterranean flora elements: Acer monspessulanum L., Carpinus orientalis Miller, Fraxinus ornus L., Quercus cerris L., Quercus pubescens Willd., Prunus mahaleb L. Miller; Pontic-Mediterranean species: Cotinus coggygria Scop., Cornus mas L., Vitis sylvestris C. C. Gmelin; 
Pontic-Balcanic species: Fagus taurica Popl., Fagus orientalis Lipsky;

Balcanic species: Corylus colurna L., Quercus frainetto Ten.;

Balcanic-Pannonian: Tilia tomentosa Moench (T. argentea DC);

Carpatian-Balcanic-Anatolian: Syringa vulgaris L.

Herbaceous species

Mediterranean: Asperula taurina L., Cynosurus echinatus L., Lychnis coronaria (L.) Desr.;

Physocaulis nodosus (L.) Tausch. = Myrrhoides nodosa (L.) Cannon, Saponaria bellidifolia Sm., rare, Smyrnium perfoliatum L., Muscari commutatum Guss., very rare;

Atlantic-Mediterranean: Ceterach officinarum Willd. ssp. officinarum, Physospermum cornubiense (L.) DC (Dannaa cornubiensis (L.) Burnat;

Submediterranean: Chrysopogon gryllus (L.) Trin., Orlaya grandiflora (L.) Hoffm.;

Submediterranean-Atlantic: Dioscorea (Tamus) communis L.;

Central-European-submediterranean: Allium flavum L.;

Pontic-Mediterranean: Paronychia cephalotes (Bieb.) Besser, Ruscus aculeatus L., Verbena supina L. (rare, Sviniţa and Tri-kule wet places); Fritillaria orientalis Adams, Cazane and Veliki Strbac Mountain, Serbia (Tomovici et al., 2007);

Pontic-balcanic-Pannonian. Ruscus hypoglossum L.;

Balcanic: Campanula lingulata Waldst. and Kit., Cephalaria laevigata (W. and K.) Schrad., Crocus flavus Weston (= C. moesiacus Ker.-Gawl), Symphytum ottomanum Friv.,

Helleborus odorus Waldst. and Kit., Sesleria filifolia Hoppe, Daco-Balcanic: Seseli rigidum Waldst. and Kit.;

Daco-Balc-Illir.: Centaurea atropurpurea Waldst. and Kit.;

Carp-Balc: Cerastium banaticum (Rochel) Heuffel, Erysimum comatum Pancic (E. saxosum Nyár.);

Alpin-Carp-Balc: Achnatherum calamagrostis (L.) Beauv., Geranium macrorrhizum L., Peltaria alliacea Jaq. (rare);

Endemic: Pinus nigra L. ssp. banatica (Borbás) Novák, (Southern Carpathians), Athamantha hungarica Borbás = A. turbith (L.) Brot. ssp. hungarica (Borbás) Tutin;

South-Eastern European-Asia Minor: Cardamine graeca L., rare (Roman, 1972a).

In the relatively narrow and part-deeply incised valleys of the Danube tributaries occurring many European mesophilous and meso-hygrophilous species characteristic of the montane level of the Carpathians. These include for example Telekia speciosa and Petasites hybridus. Accompanying the water courses they reach in the area down to low altitudes of 80-90 $\mathrm{m}$ a.s.l. These species that identify tall herbaceous wet fringe communities are of great interest from the ecological and the phytogeographical point of view.

Of the 548 taxa listed in the Red Book of vascular plants of Romania (from a total of 3,795 species and subspecies in the Romanian flora) a total of 102 occur in the Danube Gorge break area. These belong to the following categories of degree of threat (Tab. 1):

Table 1: Red book species of the Danube Gorge according to their threat category.

\begin{tabular}{|c|c|c|c|c|c|c|c|c|}
\hline $\begin{array}{c}\text { Species } \\
\text { and ssp. } \\
\text { of } \\
\begin{array}{c}\text { Romanian } \\
\text { flora }\end{array}\end{array}$ & $\begin{array}{c}\text { Species } \\
\text { and } \\
\text { ssp. } \\
\text { Red } \\
\text { Book }\end{array}$ & $\begin{array}{c}\text { Red book } \\
\text { species and } \\
\text { ssp. of the } \\
\text { Clisura } \\
\text { area }\end{array}$ & CR & VU & EN & LR & DD & EX \\
\hline 3,975 & 548 & 102 & 39 & 26 & 21 & 12 & 3 & - \\
\hline
\end{tabular}


Most of them belong to the same categories of phytogeographical elements as the above-mentioned species. A great number are Southern (Mediterranean, sub-Mediterranean, Balcanic) species that reach the Northern limit of their distribution in the Danube Gorge. These include for example Euphorbia myrsinites, Ferula heuffelii and Fumaria kraliki (see the list below). Others, as for example Daphne laureola and Gagea bohemica, attain in the Danube cross valley area the North-Eastern limit of their distribution. Some European and Central European species such as Asplenium adulterinum, Minuartia capillacea or Stipa eriocaulis occur in the Danube Gorge area at the Eastern limit of their distribution area. Cardamine enneaphyllos, an European species, reaches in the Danube Gorge the SouthEastern limit of its occurence, being rare in the area. Thlaspi jankae occurs in the gorge area on its Southern border. Finally there are also present Eastern taxa such as Paeonia mascula ssp. tridentata and Silene spergulifolia, which reach in the mountains around the Danube Gorge area the Western limit of their distribution. These facts underlines the position of the Danube Gorge break area as a meeting, crossing and interlocking point of species from different phytogeographical zones and different distribution area.

List of species of the Danube Gorge break area and surroundings included in the Red Book of vascular plants of Romania (Dihoru and Negrean, 2009) in alphabetical order with their category of threat and distribution data.

Acanthus balcanicus Heywood et I. B. K. Richardson (A. longifolius Host non Poiret), Balc., VU (Dihoru and Negrean, 2009), on the Northern limit of its distribution area.

Acinos rotundifolius Pers., Med-submed, LR, on the North-Western limit of its distribution area.

Aethionema saxatile R. Br., Med (montan), CR, on the Northern limit of its distribution area.

Alyssoides utriculata (L.) Medit., submed., CR, on North-Estern limit of its area.

Alyssum montanum ssp. gmelini (Jord.) Em. Schmid., Ec-Eu-Ct, LR

Alyssm pichleri Velen., rare, Balc., CR, on the Northern limit of its area. Recently the species has not been found in the mentioned area of the Danube cross valley between Drencova and Svinița, as well Vârciorova area (Dihoru and Negrean, 2009).

Alyssum pulvinare Velen., Balc, CR, on the Northern limit of its area.

Alyssum stribrnyi Velen., rare, Balc-Anat., DD.

Alyssum wierzbickii Heuffel, Dac-Balc, CR, Clisura, gorge of Nera and Beuşnița.

Asplenium adulterinum Milde, Central European endemic species, "exceptionally rare" (Dihoru and Negrean, 2009), CR, on the Eastern limit of its distribution area.

Asplenium lepidum C. Presl., submedit, CR, on the North-Eastern limit of its area.

Asplenium onopteris L., Atl.-Medit., EN, on the N-E limit of its distribution area (Dihoru and Negrean, 2009).

Campanula crassipes Heuffel, rare, Dac., EN, small distribution area.

Cardamine enneaphyllos (L.) Crantz, Central-Eur., European Endemic species, very rare (Cheile Nerei and Beuşniţei), CR, on the South-Eastern limit of its distribution area.

Centaurea calvescens Pancic, Moesian flora element. VU, on the Northern limit of its distribution area.

Cephalorhynchus tuberosus (Steven) Schian, East-Submedit., VU, on the Northern limit of its distribution area. 
Cirsium creticum (Lam.) d'Urv., ssp. creticum, Medit., EN, only in South-Western part of Romania, on the Northern limit of its distribution area.

Colchicum arenarium Wald. et Kit., Danubian endemic species - Geto-Pannonian (Dihoru and Negrean, 2009), EN, rare, Ostrovul Moldova Veche.

Convolvulus althaeoides L. ssp. tenuissimus (Sibth. and Sm.) Stace., Balc.-Anatolian, EN, very rare (Sviniţa).

Coronilla emerus L. ssp. emeroides (Boiss. and Spruner) Hayek, Medit., VU, rare (1972b, Dihoru and Negrean, 2009), only in South-Western Romania, on the Northern limit of its distribution area.

Daphne laureola L., Atl.-Medit., very rare, VU, North-Eastern limit of its area.

Dianthus giganteiformis Borbás ssp. kladovanus (Degen) Soó, Geto-Moesian (Balc.) element, subend., $\mathbf{C R}$, very small distribution area.

Dianthus pinifolius Sm. in Sibth. and Sm. ssp. serbicus Wettat., Balc, CR, rare, on the Northern limit of its area.

Eleocharis mitracarpa Steud., Euro-asiatic, VU, rare, on the Western limit of its distribution area.

Elymus panormitanus (Parl.) Izelev, Medit., VU, on the Northern limit of its distribution area.

Euphorbia myrsinites L., Medit., EN, on the Northern limit of its area.

Ferula heuffelii Griseb. ex Heuff., Dac.-Balc., rare, EN, on the Northern limit of its area.

Fumaria kralikii Jord., Eu-Medit., rare, DD, on the Northern limit of its distribution area.

Fumaria petteri Rchb. ssp. thuretii (Boiss.) Pugsley, Medit., rare, DD, on the northen limit of its distribution area.

Gagea bohemica (Zausch.) Schultes and Schult., submedit., rare, CR-DD, on the NorthEastern limit of its area.

Galium lucidum All., rare, Medit.-submedit., VU, on the North-Eastern limit of its European area, Beuşniţa Basin.

Genista januensis Viv., Apen.-Balc-Dac, CR-DD, on the Northern limit of its area.

Genista radiata (L.) Scop., Alp.-Apen.-Balc.-Dac., CR-DD, Beuşniţa Basin, Anina Mountains, on the Northern limit of its area.

Gladiolus illyricus Koch, Medit., rare (Mraconia Valley), CR, on the North-Eastern limit of its distribution area.

Herniaria hirsuta L. ssp. hirsuta, Submedit., rare, CR, Northern limit of its distribution area. On flooded area of the Danube Gorge break. As a consequence of the construction of the "Iron Gates" Dam the species has almost disappeared.

Hippocrepis comosa L., Atl-Medit., VU, rare.

Hordeum bulbosum L., Medit., rare; CR, on the Northern limit of its distribution area.

Hypericum rochelii Griseb. and Schenk, Dac-Balc, EN, very rare (Berzeasca in the Sirinia Valley), on the limit of its distribution area.

Iris reichenbachii Heuff., LR, Dac-Balc (Moesian), Northern limit of its distribution area (Danube Gorge, Cheile Nerei and Beuşniţei Valley, and Cerna Valley).

Jasione heldreichii Boiss. and Orph in Boiss., Dac.-Balc., VU, Trescovăţ Mountains, near Sviniţa (locus clasicus), Northern limit of its distribution area.

Lathyrus cicera L., Medit., VU, (Vârciorova).

Lotus angustissimus L., Atl.-Submedit., EN, Orşova. 
Ludwigia palustris (L.) Elliott, EN, An-Subatl-Medit (Afro-Euro-American), on Moldova Veche Islet, on fine-grained sands (not reconfirmed).

Matricaria trichophylla (Boiss.) Boiss., Dac.-Balc.-Anat., VU, on the Danube (Vârciorova, Orşova).

Medicago polymorpha L., Submedit., VU, rare, on the Northern limit of its distribution area. Minuartia capillacea (All.) Graebner in Ascherson and Graebner, Alp.-Balc.-Dac., very rare, Eastern limit of its area.

Minuartia cataractarum Janka, Dac., very rare, VU.

Minuartia graminifolia (Ard.) Jáv., Dac.-Medit, rare, LR, Northern limit of its area.

Minuartia hamata (Hauskn. and Bornm.) Mattf., Medit.-submedit, EN, extremely rare on the Danube sunny and sandy hill slopes between Schela Cladovei and Oglanic, on the Northern limit of its distribution area.

Minuartia hirsuta (Bieb.) Hand.-Mazz. ssp. falcata (Griseb.) Mattf., Balc-Anat., EN, very rare (Sviniţa at Tri Kule, Gura Văii and Vârciorova), on the Northern limit of its distribution area.

Notholaena maranthae (L.) Desv., Med-submed., EN, very rare, on the Northern limit of its distribution area.

Onobrychis alba (Waldst. and Kit.) Desv., Balc.-Apen.-Dac., LR, very rare Nera-Beuşniţa), Northern limit of its distribution area.

Ophrys apifera Huds. ssp. apifera, Atl-Med, CR, very rare, (Sviniţa-Tri Kule),

Ophrys scoplopax Cav. ssp. cornuta (Steven) Camus, Submedit., CR, very rare, NorthEastern limit of its distribution area.

Orchis pallens L., submedit, rare, $\mathbf{C R}$.

Orchis papilionacea L., Medit., LR, rare, on the Northern limit of its area.

Orchis simia Lam., Atl-Submed, EN, rare.

Ornithogalum sphaerocarpum A. Kern., Submedit, CR, rare, North-Eastern limit of its area. Paeonia mascula (L.) Mill., ssp. mascula, Submedit, CR very rare (only in the Ciclova Valley below Simion Peak and Beuşniţa Basin), On the North-Eastern limit of its distribution area.

Paeonia mascula (L.) Mill., ssp. triternata (Pall. Ex DC) Stearn and P. H. Davis (P. daurica Andrews (L.) DC), Cauc-Taurian-Anatolian-Getic (Dihoru and Negrean, 2009); rare CR, (Ciocanu Mountains near to Vârciorova), on the Western limit of its area.

Paeonia officinalis L. ssp. banatica (Rochel) Soó, Pannonian, CR, very rare, Baziaş, Eastern limit of its area.

Parietaria lusitanica L. ssp. serbica (Pancic) P. W. Ball., Dac-Moesic-Dobrogean, EN, extremely rare.

Paronychia kapela (Hacq.) A. Kern., Submedit., CR, very rare (Vârciorova-Schela Cladova, Cerna Valley), North-Eastern limit of its area.

Petrorhagia illyrica (Ard.) P. W. Ball and Heywood ssp. haynaldiana (Janka) P. W. Ball and Heywood, Medit-submed, CR, very rare, Northern limit of its distribution area.

Piptatherum holciforme (M. Bieb.) Roem. and Schult., Medit-East (Balc-TaurianAnatolian), CR, rare, North-North-Western limit of its distribution area.

Polycarpon tetraphyllum (L.) L. ssp. tetraphyllum, Atl-Medit-submedit, CR, very rare, on the Northern limit of its area. 
Polygala supina Schreber ssp. hospita (Heuffel) McNeill, Dac., CR, very rare (Sviniţa), unique locality in Romania for the taxon.

Prangos carinata Griseb. ex Degen, Dac., VU, hills slopes between Vârciorova and Gura Văii, "Iron Gates" (locus classicus).

Psilurus incurvus (Gouan) Schinz and Thell., Medit., EN, Northern limit of its area.

Ranunculus flabellifolius Heuff. and Rchb., Dac., VU, very small area.

Rhinanthus alectorolophus (Scop.) Pollich, Central-European, VU, South and South-Eastern limit of its area.

Saccharum strictum (Host) Spreng., Eastern-Medit., rare, CR, Northern limit of its area.

Sagina apetala Ard., Atl-Medit., CR, rare.

Salvia amplexicaulis Lam., Balc-Anatolian, very rare. EN, on the Northern limit of its area.

Saponaria glutinosa Bieb., Medit, LR, small populations.

Satureja montana L. ssp. kitaibelii (Wierzb.) P. W. Ball., Balc (Moesian), LR, rare, Northern limit of its area.

Scorzonera lanata (L.) Hoffm., Eastern submedit., CR, extremely rare, on the NorthWestern limit of its area.

Scutellaria columnae All. ssp. columnae, submedit., CR, rare (Danube Gorge, Nera in Gorj), on the North-Eastern limit of its area.

Scutellaria velenovskyi Rech, CR, Dac-Balc-Anatolian, very small area, on the Northern limit of its distribution area.

Sedum dasyphyllum L., Medit-submedit., EN, rare, North-Eastern limit of its area.

Sedum ochroleucum Chaix in Vill., Medit, EN, North-Eastern limit of its distribution area.

Silene flavescens Waldst. and Kit., Balc-Pan., LR.

Silene gallinyi Rchb. Apen-Balc, CR, rare, Northern limit of its distribution area.

Silene spergulifolia (Willd.) M. Bieb., Medit.-Cauc., LR, Western limit of its area.

Sison amomum L., Atl.-Medit-Anat, VU, Cerna Valley.

Sorbus borbásii Jáv., Dac, VU, small distribution area.

Spergula pentandra L., Medit-submed., CR, rare, near to the Eastern limit of its area.

Sternbergia colchiciflora Wald. and Kit., submedit. (Svinița), LR.

Stipa bromoides (L.) Dörfl., submedit-medit., CR, rare, near the Northern limit of its area.

Stipa danubialis Dihoru and Roman, Dacian endemic species, CR.

Stipa eriocaulis Borbás, submedit-Medit, LR, Eastern limit of its area.

Thlaspi dacicum Heuff. ssp. banaticum (Uechtr.) Nyár., Dac., VU, Cerna Valley.

Thlaspi jankae A. Kerner, Pannonian, EN, extremely rare (North-West of Drobeta-TurnuSeverin), Southern limit of its area.

Tragopogon balcanicus Velen., Dac-Balc, VU, rare, North-Western limit of its area.

Trifolium subterraneum L., Medit, CR, Northern limit of its area.

Tulipa hungarica Borbás, Dac, local endemic species, CR.

Verbascum pulverulentum Vill., Atl-Medit, on the North-Eastern limit of its area, VU,

Verbasum vandasii (Rohlena) Rohlena, VU, Dac-Balc (Moesian), North-Eastern limit of its distribution area.

Veronica crassifolia Wierzb. ex Heuff., Dac-Balc (Moesian), VU, rare.

Veronica scardica Griseb. Submedit., VU, rare.

Vicia truncatula Fisch., ex M. Bieb., Moesian-Dac-Anatolic, Caucasian, CR, Northern limit of its distribution area.

Vulpia ciliata Dumort., Medit., EN, on the Northern limit of its distribution area. 
With regard to the larger vegetation units existing on the rocky slopes of the Danube Gorge break valley the most characteristic for the sub-Mediterranean vegetation are the "Shibliac" scrub formations of both sides of the Danube Gorge break in Romania and Serbia (Fig. 2), identified by Wild lilac (Syringa vulgaris), Oriental hornbeam (Carpinus orientalis), Manna or Flowering ash (Fraxinus ornus), Wig bush (Cotinus coggygria), locally in the "Cazanele Mari", also Montpellier maple (Acer monspessulanum) and others. They are identifying plant communities of the alliances Orno-Cotinion, Querco-Carpinion orientalis and Syringo-Carpinion orientalis (Sanda et al., 2008; Niculae, 2014).

If we compare the species composition from the characteristic phytocoenoses of the area of interest, exemplified by the two associations Syringo-Cotinetum orientalis Jakucs 1959 and Echinopo banatici-Quercetum pubescentis Boşcaiu et al. 1971 (Figs. 3 and 4), the number of Mediterranean and sub-Mediterranean species are prevalent. If we were to take into account not only the number of species but also the abundance-dominance values of the identifying species, the representativeness of the Southern categories of phytogeographical elements in the association would be even more distinct. Such examples can be given also by other characteristic phytocoenoses of the area, by forest vegetation with the association Quercetum cerris-carpinetosum orientalis (Resmeriţă et al., 1972) including many subMediterranean and Balcanic species and also with open rocky slopes, their natural grasslands and crevice vegetation. Also the semi-natural grasslands, common in the localities of the neighbouring area are characterized by Southern species. More widespread in the Clisura area and Southern Banat are phytocoenoses of the association Chrysopogonetum grylli banaticum (Resmeriţă et al., 1971), identified by the subMediterranean grass species Chrysopogon gryllus and accompanied by many other subMediterranean species.

Both, the "Iron Gates" Natural Park in Romania and the "Djerdap" National Park on the Danube in Serbia shelter a great number of plant communities of high interest from a biogeographical point of view. As the area is under the influence of a sub-Mediterranean climate, the habitats differs from those of other parts of the Carpathians, but the transition is gradually with radiation till the Mureş Valley and even North of the Mureş in the Apuseni Mountains.

The habitats occurring in the Danube cross valley and surrounding area, including each characteristic phyto- and zoo-coenoses are preponderantly of relevance for the Natura 2000 network.

The habitat type 40A0* Subcontinental peri-Pannonic scrub includes a large number of associations of the order Syringo-Carpinion orientalis Jakucs 1959, most of them relicts from the Tertiary age. Characteristic species for the alliance are: Syringa vulgaris, Carpinus orientalis, Campanula lingulata, Celtis australis, Dianthus giganteus ssp. giganteus, Cardamine graeca, Echinops banaticus, Ferula heuffelii, Hypericum rochelii, Piptatherum holciforme, Scabiosa banatica, Scutellaria pichleri, and others.

Taking into account the distribution area of Syringa vulgaris (Meusel and Niedermaier, 1985; Horvat et al., 1974) and the most of identifying species of the association Syringo-Carpinetum orientalis, it becomes clear that they exceed by far the PeriPannonian region, being of importance over a larger area, i.e. the whole Balcanic-Eastern sub-Mediterranean region (Fig. 5). 


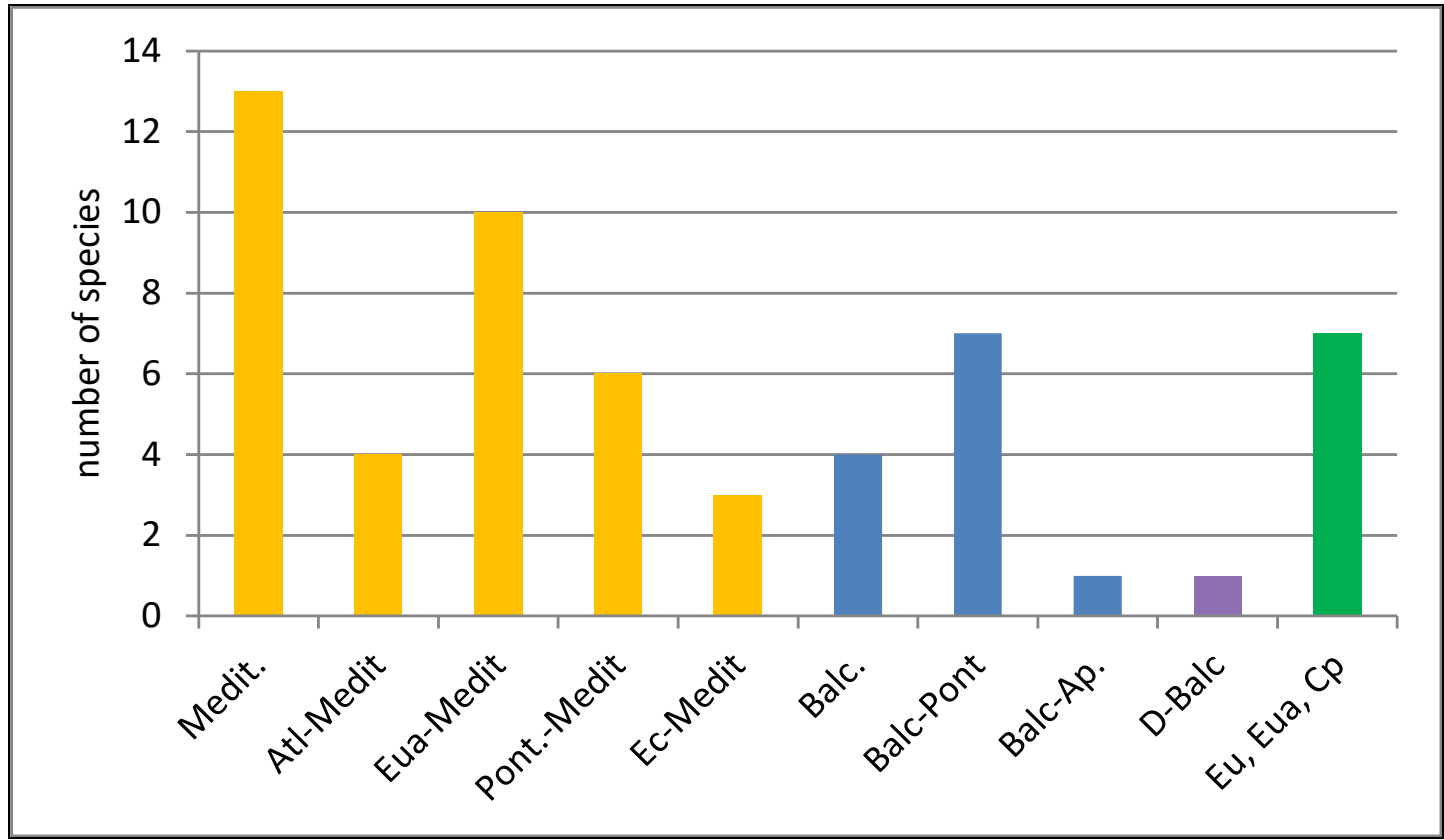

Figure 3: Syringo-Carpinetum orientalis Jakucs 1959

represented by groups of phytogeographical elements (according to data of phytocoenological tables by Boşcaiu et al. (1971), completed with recent field data 2014).

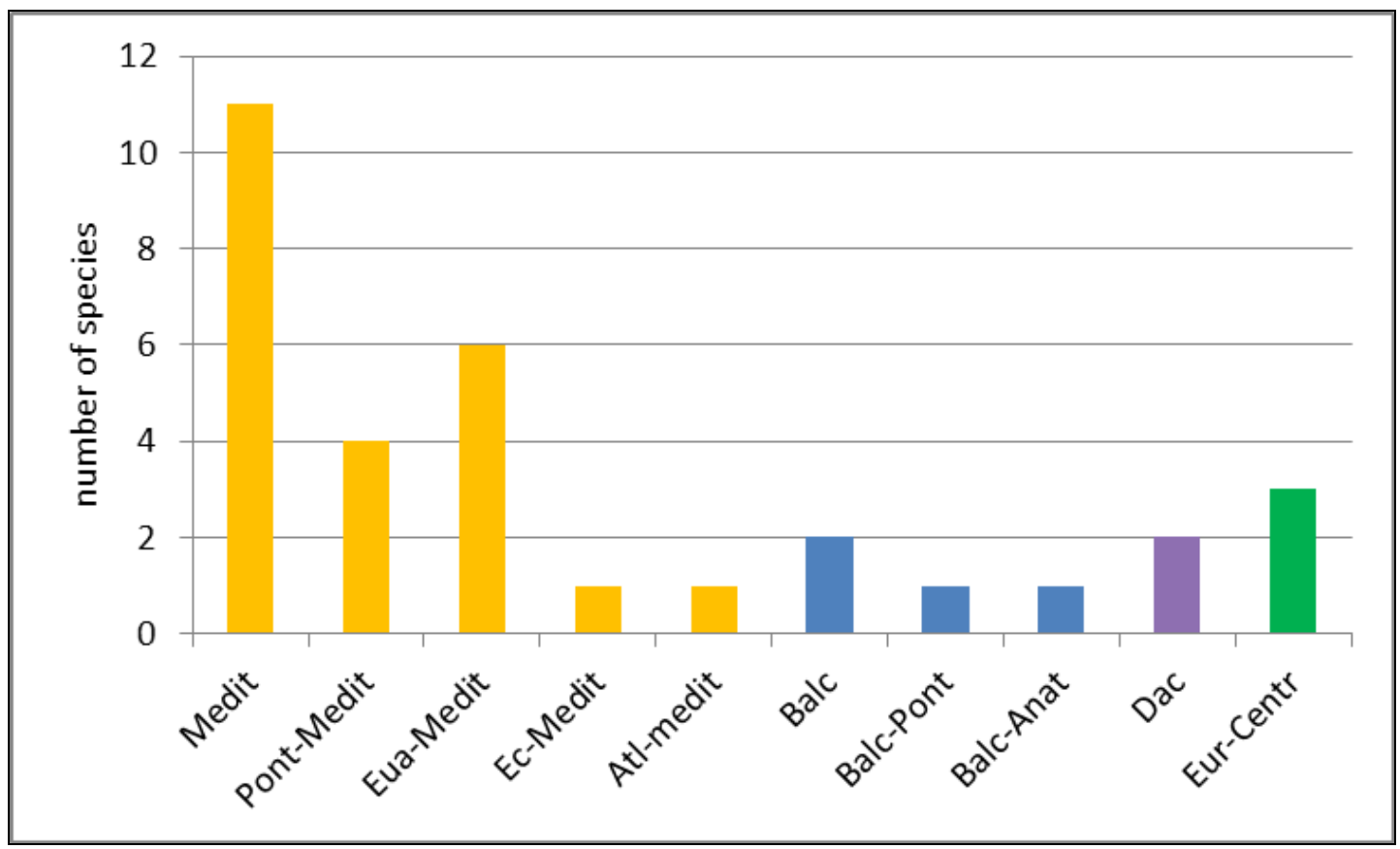

Figure 4: Echinopo banatici-Quercetum pubescentis Boşcaiu et al. (1971)

(= Acantho longifolii-Quercetum pubescentis Jakucs and Fekete 1958)

represented by groups of phytogeographical elements

(according to data in Boşcaiu 1971 completed by new data 2014). 


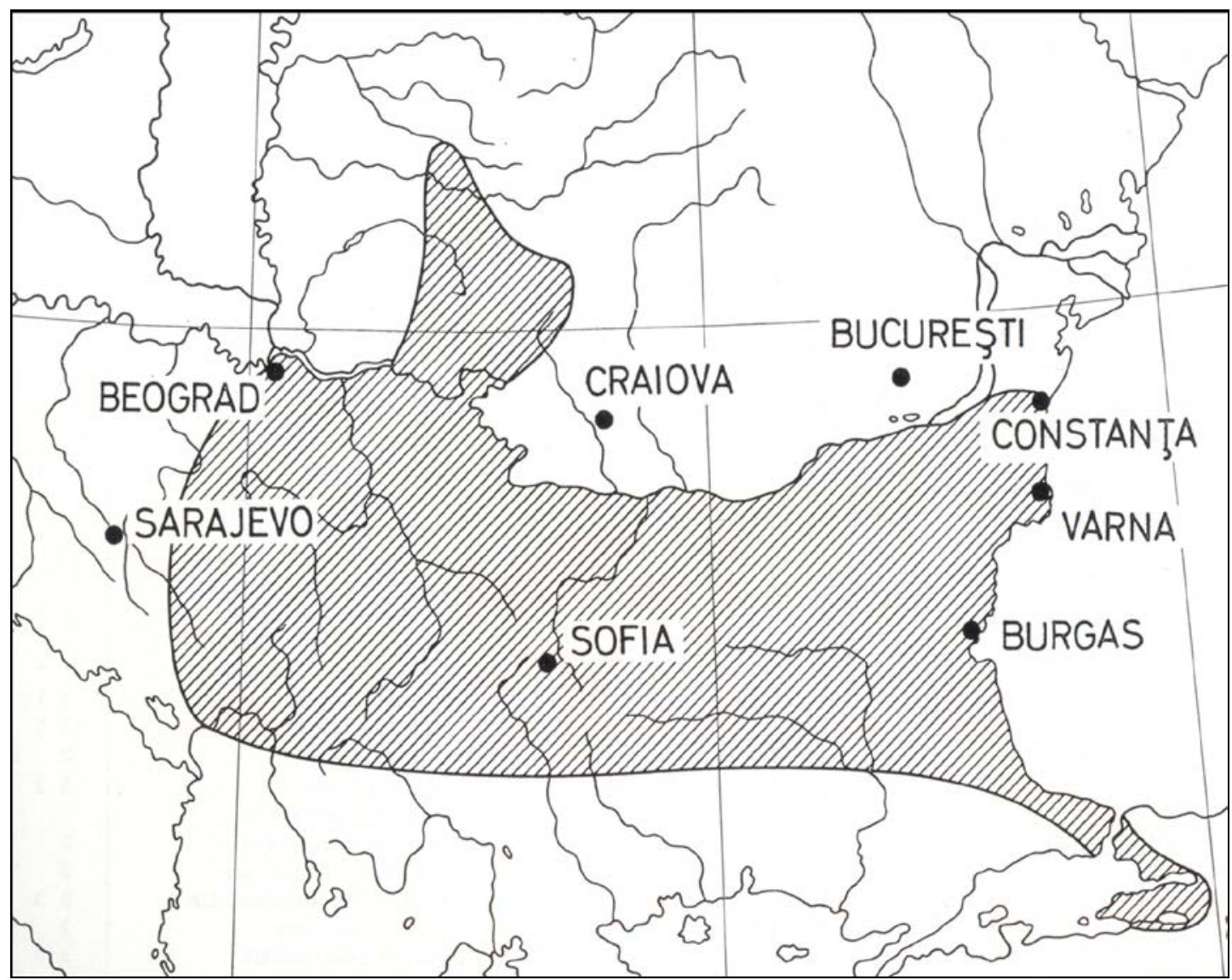

Figure 5: Distribution area of Syringa vulgaris (Horvat et al., 1974).

Other characteristic habitat types for the Danube Gorge break area are natural grasslands including the habitat types $6110^{*}$ Rupicolous or basophile grasslands of the Alysso-Sedion albi and 6190 Rupicolous pannonic grasslands (Stipo-Festucetalia pallentis). Included are grasslands on the rocky slopes of the Clisura area between Sviniţa and Mraconia valleys (Schneider-Binder et al., 1970, 1971).

The semi-natural dry grasslands and scrubland facies are represented by the habitat types 6210 Semi-natural dry grassland and shrubland facies on calcareous substrates (Festuco-Brometalia, * important orchid sites) and 6240* Sub-Pannonic steppic grasslands. Included are grasslands of Chrysopogon gryllus, widespread in the Southern Banat and included in the association Danthonio-Chrysopogonetum grylli Boşcaiu (1970) 1972, Campanulo lingulatae-Brometum riparii (Roman, 1974) Sanda and Popescu 1999 (Roman, 1974; Gafta and Mountford, 2008).

The habitat type 6430 Hydrophilous tall herb fringe communities of plains and of the montane and alpine levels occurs in the small valleys of Danube tributaries where the characteristic species Telekia speciosa reaches the low altitude of around $80 \mathrm{~m}$. These fringes with Telekia speciosa and Petasites hybridus are in strong contact with the TilioAcerion forests of the slopes, screes and ravines. 
The rocky habitats of the Clisura area which are of interest are well represented by habitat types of siliceous and calcareous rocks substrate being strongly related to the mosaic of geological underground (Mutihac, 1972). The habitat type 8120 Calcareous and calcareous schist screes of the montane to alpine levels (Thlaspietea rotundifolii) is represented in the valleys of tributaries of the Danube Clisura area with phytocoenoses of the association Sedo fabariae-Geranietum macrorrhizi Boșcaiu and Täuber, 1977. Occurring as well in the area is the habitat type 8160* Medio-European calcareous scree of hill and montane levels in association with Stipetalia calamagrostis (EUR 28, 2013) with phytocoenoses of the association Achnatheretum calamagrostis Br.-Bl. 1918, which reaches the Northern limit of its distribution area in the South-Western Carpathians (Banat).

The rocky slopes with crevices occurring in the area are represented by the habitat type 8210 Calcareous rocky slopes with casmophytic vegetation, subtype 62.15 and 62.1 B Euro-Siberian communities and Mediterranean communities in different variants.

The shady communities of this subtype of habitats are those identified by the fern species Cystopteris fragilis, Asplenium trichomanes, Asplenium viride and the endemic phytocoenoses of Campanula crassipes. Xerophilous communities are represented by those identified mainly by Ceterach officinarum and Asplenium ruta-muraria.

Large areas of the Danube Gorge area and tributary valleys are covered by forests characteristic of temperate Europe with Central-European to South-Eastern EuropeanCarpathian character, as well as forests with Moesian, Illyrian and Balcanic specificity with many termophilous species. The following forest habitat types occur in the area: 9110 Luzulo-Fagetum beech forest (small area), 9130 Asperulo-Fagetumbeech forest, 9150 Medio-European limestone beech forests of the Cephalanthero-Fagion, 9180* Tilio-Acerion forests of slopes, screes and ravines, characteristic for the small deep valleys of tributaries, 91E0* Alluvial forests with Alnus glutinosa and Fraxinus excelsior (Alno-Padion, Alnion incanae, Salicion albae), 91 H0* Pannonian woods with Quercus pubescens, 91K0 Illyrian Fagus sylvatica forests (Aremonio-Fagion), 91L0 Illyrian oak-hornbeam forests (Erythronio-Carpinion), 91 M0 Pannonian-Balkanic turkey oak-sessile oak forests, 91V0 Dacian Beech forests (Symphyto-Fagion), 91W0 Moesian beech forests, 91Y0 Dacian oak and hornbeam forests, 91Z0 Moesian Silver lime woods and 9530*(Sub-) Mediterranean pine forests with endemic black pines (Pinus nigra ssp. banatica) (EUR 28, 2008; Schneider and Drăgulescu, 2005; Doniţă et al., 2005).

The Illyrian forests of habitat type 91K0 and 91L0 occur only in a small area (Boşcaiu, 1971), interlocking gradually with the Medio-European type forest of the other parts of Carpathians. This can be stated on the one hand by following the distribution area of Aremonia agrimonioides, a Central European-Mediterranean species characteristic for Illyrian beech forests (Aremonio Fagion) and concentrated in the Carpathians in their SouthWestern part (Oprea, 2005). On the other hand the Illyrian oak-hornbeam forest (Erythronio-Carpinion) is characterised by Erythronium dens-canis L. and its ssp. nivaeus (Baumg.) Buia and Păun, the last being concentrated in the South-Western part of Carpathians. 
The habitat type 91E0* Alluvial forests with Alnus glutinosa and Fraxinus excelsior (Alno-Padion, Alnion incanae, Salicion albae), occurs in very small area on the Danube because it suffered a loss after construction of the "Iron Gates" Dam and the barrier lake. But the habitat is present along the valleys of tributaries as gallery-type forest that is partly in a good conservation state. But on the downstream parts of tributaries suffered changes due to the backwater situation and the modification of their mouths into the backed-up Danube. Although some major changes have occurred, the Danube cross valley is of importance as an outstanding landscape area, with high biodiversity, representing the richest part of the Carpathian area. For this reason the Danube Gorge is in the attention of both countries Romania and Serbia, being under protection as a Natural Park both in Romania and Serbia with many efforts directed towards research, appropriate management and conservation (Niculae, 2014; Macura et al., 2010).

\section{CONCLUSIONS}

The Danube Gorge break valley is of high value and importance for its outstanding biodiversity and presents great interest from the biogeographical and nature conservation point of view. It shelters many Southern species that attain here their northernmost distribution limits, species that lend a sub-Mediterranean character to the vegetation of the Danube Gorge. For some of the sub-Mediterranean and Illyric-Mediterranean species the mountains around the Danube cross valley is their distribution route to the North-East as far as the Poiana Ruscă and Apuseni Mountains and even from there to the Transylvanian Basin.

At the same time the Clisura constitutes the Southern or South-eastern limit for Central European species and the Western limit of species of Pontic or PonticMediterranean origin. It is a crossing and interlocking point of species characteristic for different biogeographical regions.

The Clisura functions also as a connection corridor for many species from upstream to downstream and from the right to the left side of the Danube. This function has been disturbed by the "Iron Gates" water reservoir, a barrier lake, which has changed the hydrological dynamics of the river and that of the mouth of tributaries modified by sedimentation and ponding due to the backwater situation. Overall the whole complex of the Clisura and surrounding area, with the forests, the rocky slopes and their specific vegetation is of outstanding value and needs further attention from the scientific, practical protection and conservation point of view. 


\section{REFERENCES}

1. Borza A., 1931a - Die Vegetation und Flora Rumäniens. Guide de la sixième Excursion Phytogéographique Internationale, Roumanie 1931, Jardin Botanique de l'Université de Cluj, 1-55. (in German)

2. Borza A., 1931b - Botanischer Führer durch die Umgebung von Băile Herculane (Herkulesbad) bis an die Donau. Guide de la sixième Excursion Phytogéographique Internationale, Roumanie 1931, Jardin Botanique de l'Université de Cluj, 56-63. (in German)

3. Borza A. and Boşcaiu N., 1965 - Introducere în studiul covorului vegetal, Edit. Academiei R. S. România, Bucureşti, 340. (in Romanian)

4. Boşcaiu N., 1971 - Flora şi vegetaţia Munţilor Ţarcu, Godeanu şi Cernei, Edit. Academiei R. S. România, 464. (in Romanian)

5. Boşcaiu N., Lupşa V., Resmeriţă I., Coldea G. and Schneider E., 1971 - Vegetaţia lemnoasă mezo-xerotermă (Orno-Cotinetalia) din Defileul Dunării, Ocrotirea Naturii, 15, 1, 49-55, Edit. Academiei R. S. România, Bucureşti. (in Romanian)

6. Călinescu R., 1969 - Biogeografia României, Edit. Ştiinţifică, Bucureşti, 412. (in Romanian)

7. Ciocârlan V., 2009 - Flora ilustrată a României. Pteridophyta et Spermatophyta, Edit. Ceres, Bucureşti, 1141. (in Romanian)

8. Dihoru G. and Negrean G., 2009 - Cartea Roşie a plantelor vasculare din România/Red book of vascular plants of Romania, Edit. Academiei Române. Bucureşti, 630. (in Romanian)

9. Doniţă N. and Roman N., 1976 - Atlasul Republicii Socialiste România, foaia VI-2. Vegetaţia/Vegetation. Unităţi zonale pe altitudine, Edit. Academiei Române, Bucureşti. (in Romanian)

10. Doniţă N., Popescu A., Paucă-Comănescu M., Mihăilescu S. and Biriş I. A., 2005 Habitatele din România, Edit. Tehnică Silvică, Bucureşti, 496. (in Romanian)

11. EUR28, 2013 - Interpretation Manual of the European Union habitats. European Commission DG Environment, 144.

12. Gafta D. and Mountford O., 2008 - Manual de interpretare a habitatelor Natura 2000 din România, Risoprint, Cluj-Napoca, 101. (in Romanian)

13. Horvat I., Glavac V. and Ellenberg H., 1974 - Vegetation Südosteuropas. Vegetation of South-Eastern Europe, 768.

14. Macura B., Bojovic D., Petric I., Cosic N., Tadic M., Jaric I., Knezevic J., Spiric J. and Jaric M., 2010 - Local Communities and Management of Protected Areas in Serbia. Ecological Society ENDEMIT, 29.

15. Meusel H. and Niedermaier K., 1985 - Dei Breitlaubwälder des Süd- und Ostkarpatenraumes in vergleichend chorologischer Sicht. Naturwissenschaftliche Forschungen über Siebenbürgen. III, Beiträge zur Pflanzengeographie des Südost-Karpatenraumes, 1-42, Siebenbürgisches Archiv Band 20, Böhlau Verlag Köln Wien. (in German)

16. Mutihac V., 1972 - Structura geologică, in Atlasul complex „Porţile de Fier”, 20, 134-136, Edit. Academiei R. S. România, Bucureşti. (in Romanian)

17. Niculae M.-I., 2014 - Integrated Management of biological and landscape diversity for sustainable regional Development and ecological connectivity in the Carpathians (Bioregio Carpathians). Study on the methodology for identification, characterization and classification of landscapes from the cross-border area "Iron Gates" natural Park and Djerdap National Park, Southeast Europe Transnational Cooperation Programme, Bioregio Carpathians, Romsilva, Parcul Natural Porţile de Fier, Ramsar, European Union, 10.

18. Niklfeld H., 1973 - Natürliche Vegetation/Natural vegetation, in Atlas der Donauländer/Atlas of the Danubian countries, Map volume/Map number 171. Distributed on commission by: Franz Deuticke Verlags- und Universitätsbuchhandlung, Wien/Vienna 19701989, edited and redacted on behalf of the Federal Ministry of Science and Research and in the name of the Austrian Institute of East and South-East European Studies by Breu J. 
19. Oprea A., 2005 - Lista critică a plantelor vasculare din România, Edit. Universităţii „Alexandru Ioan Cuza” Iaşi, 668. (in Romanian)

20. Popova-Cucu A., 1978 - Atlasul Republicii Socialiste România, foaia VI-5, 2. Regiunile fitogeografice, Edit. Academiei Române, Bucureşti. (in Romanian)

21. Popova-Cucu A. and Bunescu A., 1974 - Atlasul Republicii Socialiste România, Elemente fitogeografice şi zoogeografice, VI-3, 1-8 elemente fitogeografice, 9-14 elemente zoogeografice, Edit. Academiei Române, Bucureşti. (in Romanian)

22. Posea G., 2002 - Geomorfologia României. Relief - tipuri, geneza, evoluţie, regionare. Universitatea Spiru Haret, Edit. Fundației România de mâine, București, 444. (in Romanian)

23. Resmeriţă I., Vicol E. C., Boşcaiu N., Coldea G. and Täuber F., 1972 - Vegetaţia din sectorul Ieşelniţa-Tri Kule, in Atlasul complex „Porţile de Fier”, Edit. Academiei R. S. România, Bucureşti, 47. (in Romanian)

24. Roman N., 1972a - Cormophyta: Taxoni rari, in Atlasul complex „Porţile de Fier”, Edit. Academiei R. S. România, Bucureşti, 43. (in Romanian)

25. Roman N., 1972b - Vegetaţia din sectorul Orşova-Drobeta-Turnu Severin, in Atlasul complex „Porţile de Fier”, Edit. Academiei R. S. România, Bucureşti, 46. (in Romanian)

26. Roman N., 1974 - Flora şi vegetaţia din sudul Podişului Mehedinţi, Edit. Academiei R. S. România, Bucureşti, 222. (in Romanian)

27. Sanda V., Öllerer K. and Burescu P., 2008 - Fitocenozele din România, Sintaxonomie, structură, dinamică şi evoluţie, Edit. Ars Docendi, Universitatea din Bucureşti, 570. (in Romanian)

28. Săndulescu M., Kräutner H., Borcoş M., Năstăseanu S., Pătrulius D., Ştefănescu M., Ghenea C., Lupu M., Haralambie S., Bercea I. and Marinescu F., 1978 - Atlasul Republicii Socialiste România, Foaia II-1 Harta geologică/Geological map, Institutul de Geografie, Edit. Academiei R. S. România, Bucureşti. (in Romanian and English)

29. Sârbu I., Ştefan N. and Oprea A., 2013 - Plante vasculare din România. Determinator ilustrat de teren, Edit. Victor B., Bucureşti, 1231. (in Romanian)

30. Schneider-Binder E., Boşcaiu N., Coldea G., Lupşa V., Plămadă E. Resmeriţă I. and Stoicovici L., 1970 - Zur Felsenvegetation der Sektoren Eşelniţa-Mraconia und Cazan-PassTricule (Durchbruchtal der Donau), Revue Roumaine de Biologie, Série de Botanique, 15, 5, 311-322. (in German)

31. Schneider-Binder E., Boşcaiu N., Coldea G., Lupşa V. and Resmeriţă I. 1971 - Zwei neue xerotherme Felsengesellschaften aus dem Durchbruchtal der Donau, Revue Roumaine de Biologie, Série de Botanique, 16, 2, 97-103. (in German)

32. Schneider-B. E. and Drăgulescu C., 2005 - Habitate şi situri de interes comunitar, Edit. Universităţii „Lucian Blaga” Sibiu, 167. (in Romanian)

33. Tomovic G., Vukojicic S., Niketic M., Zlatkovic B. and Stevanovic V., 2007 - Fritillaria (Liliaceae) in Serbia: distribution, habitats and some taxonomic notes, Phytologia Balcanica, 13, 3, 359-370, Sofia. 